\title{
Hedging in Refusal Speech Act
}

\author{
Ngusman Abdul Manaf and Ermanto \\ Fakultas Bahasa dan Seni, \\ Universitas Negeri Padang \\ ngusman1966@gmail.com
}

\begin{abstract}
The refusal speech act is quite risky to lose the face of the addressee. As far as observation of the author, refusal speech act has been frequently studied, but hedging in refusal speech act has not been thoroughly studied. Thus, this article was written to explain hedging in the refusal speech act. The source of the data was the Indonesian language spoken by native Indonesians. Data were collected by observational techniques and interviews towards native Indonesians in Indonesia. Data were analyzed qualitatively based on the speech act theory and politeness. The results of this study were, first, there are three main forms of hedging in the refusal speech act in the Indonesian language; second, a hedge is used to shape the politeness in a speech act; third, in general, the speakers used more than one hedge in a speech act; fourth, the use of form and quantity of hegdes in a speech act affects the level of politeness of speech acts; fifth, the use of the form and the quantity of hedges were adjusted to the level of face threatening acts.
\end{abstract}

Keywords-Hedging, Refusal Speech Act, Politeness, Indonesian

\section{INTRODUCTION}

Language politeness in speech acts attracts the attention of linguists and scholars. Many articles on linguistic politeness have been written by linguists and language learning experts, but articles on the use of hedging to form the politeness of speech acts are rarely conducted and have not been thoroughly studied. Articles on the use of hedging to form the politeness of speech acts need to be performed because the use of hedging in speech acts quite productive and varied. This article describes the use of hedging in refusal speech acts.

The study of politeness in speech acts in the last ten years is done by Anggraeni (2005), Manaf (2010 and 2011), Purnomo (2011), Tawalbeh and Al-Oqaily (2012), Susanto (2014), Codreanu and Debu 2014), Vega and Azókar (2014), Manaf and Amir (2015), and Yazdanfar and Bonyadi (2016). The results of these studies can be explained as follows. Anggraeni (2005) has studied the politeness of speech acts in Javanese language. Manaf (2010 and 2011) and Manaf and Amir (2015) have discussed the politeness of speech acts in the Indonesian language with an indicator of the degree of imposition and coercion to the addressee. Purnomo (2011) has examined the socio-cultural background of English, Japanese, Indonesian and Javanese tourists with their politeness strategies.

The speech strategies of native speakers of Arabic and native speakers of English have been studied by Tawalbeh and Al-Oqaily (2012). Codreanu and Debu (2014) examined politeness strategies of speech acts in Romanian, English, and Hebrew. Vega and Azókar (2014) discussed politeness strategies in the speech acts of native Spanish speakers and foreign speakers of Spanish. The politeness strategy of native speakers of Persian and English has been studied by Yazdanfar and Bonyadi (2016).

Speech act theory from Austin (1962), Searle (1975; 1976) serve as the frame of reference for thinking in this article. Refusal speech acts are speech acts for not to do request from a speaker. Theory of Politeness Principle by Leech (1983), the theory of Politeness and Politeness Strategies by Brown and Levinson (1987) also used as a standpoint in this paper. The concept of hedging as a politeness strategy refers to the concept of hedging according to Brown and Levinson (1987), Blum-Kulka (1987), and Trosborg (1995).

The purpose of this article is to explain the forms of hedging in refusal speech acts, the relationship of hedging use with the politeness in refusal speech acts, and the context of the use of hedging in refusal speech acts.

\section{METHOD}

Refusal speech acts in Indonesian are the objects examined in this article. The data of this article are refusal speech acts using hedging. The data source of this research is native speakers of Indonesian. Data were collected by observing speech act of Indonesian speaker, and interviewed native speakers of the Indonesian language. The research data was processed qualitatively by using terms of reference on the theory of speech acts according to Austin (1962), Searle (1975) and (1976) and theory of language politeness according to Leech (1983) Brown and Levinson (1987), and Blum-Kulka (1987). The concept of hedging in speech acts is referenced from Brown and Levinson (1987), Blum-Kulka (1987), and Trosborg (1995). 


\title{
III. DISCUSSION
}

There are three points discussed in this section, namely forms of hedging, politeness of speech acts, and the context of hedging usage in refusal speech acts.

\section{The form of hedging in refusal speech acts}

The use of hedging is one way from Indonesian speakers as members of the Minangkabau ethnic group to form refusal speech acts politely in the Indonesian. There are three forms of hedging used to form the politeness of refusal speech acts in the Indonesian language, namely (1) apology, (2) minimizing or softening intentions, and (3) the expression of doubt.

\author{
1. Apology \\ Apology as hedging in the refusal speech acts in Indonesian can be seen in the following examples of speeches. \\ (1) Mohon maaf, Buk. Pada saat ini, kami belum bisa melaksanakan apa yg Ibuk minta. \\ 'We are sorry, Madam. At the moment, we cannot do what you ask. \\ (2) Maaf Dik, saya kurang sependapat. \\ 'Excuse me boy, I disagree with you.'
}

Refusal speech acts (1) are performed by a principal to a woman who asks permission to sell in the schoolyard. One type of hedging used in speech acts (1) is the word maaf, Buk 'sorry, Madam'. To soften the expression of denial to the addressee, the speaker apologizes to the conversational partner. The speaker humbly places himself as a guilty person for not agreeing with conversational partner's opinion.

Refusal speech acts (2) is managed by a senior student to a junior student at a committee meeting on a university. A meeting participant rejected the other participants. One type of hedging used in speech acts (2) is the word maaf 'sorry'. To soften the speaker's refusal towards the addressee, the speaker apologizes to the addressee. The speaker humbly places himself/herself guilty for not agreeing with the opinion of the addressee. Based on the Politeness Principle Theory of Leech (1983), hedging apology belongs to modesty maxims. Moreover, based on the Speech Strategy theory of Brown and Levinson (1987), hedging apology is classified as a bald on record strategy with negative politeness gestures.

\section{Minimization and softening the intention} examples.

Minimization or softening the intention as hedging in refusal speech acts in Indonesian can be seen in the following

(3) Mohon maaf, saya kurang setuju panitia pelaksana harus membayar iuran untuk biaya pelaksanaan kegiatan.

'I am sorry, I am afraid i do not agree if the organizing committee should pay dues for the cost of implementing the activities.'

(4) Maaf Dik, saya agak keberatan dengan pemberian bantuan yang ditentukan jumlah minimalnya.

'I am sorry, I quite object to the provision of assistance that is determined by the minimum amount.'

Refusal speech acts (3) is conducted by a meeting participant to the other meeting participants in the ceremony of Independence Day of the Republic of Indonesia by the youth in an urban village. The speaker rejects the proposal of one of the meeting participants. The suggestion of the meeting participants was the committee should pay dues to help the cost of implementing the activities. One type of hedging used in speech acts (3) is the word mohon 'sorry' and kurang setuju 'do not agree'. Speaker's rejection towards conversational partner's request is softened by using hedging in the form of mohon 'sorry' and kurang 'afraid'. The use of the word mohon 'sorry' means that the speaker humbles himself/herself as the ruled party and the addressee is positioned as the ruling party. The use of the word kurang 'afraid' implies that the addressee is rejected by the speaker, but not in absolute manner.

Refusal speech acts (4) is conducted by a headman to a young man who will execute the activities of the Independence Day of the Republic of Indonesia. Speaker rejected the youth's plan to gather donations from residents which have already determined the minimum amount. One type of hedging used in speech acts (4) is the phrase agak keberatan 'quite object'. Rejection of the speaker upon addressee's request softened with the use of hedging in the form of phrase agak kebertan 'quite object'. The use of the phrase agak keberatan 'quite object' implies that the addressee is rejected by the speaker, but not absolutely.

Based on the Politeness Principle theory by Leech (1983), hedging softening and minimizing the meaning of speaker belongs to the maxim of generosity, whereby the speaker minimizes the benefit and maximizes the cost. Along with that, based on Speech Strategy theory from Brown and Levinson (1987), hedging apology is bald on record strategy with negative politeness gestures, i.e., the speaker try not to interfere with the freedom of the addressee. 


\section{Statement of doubt and limitation the intent}

The statement of doubt and limitation of intent as hedging in the act of refusing in Indonesian language can be seen in the following examples.

(5) Kalau tidak salah, beras bantuan pemerintah hanya diberikan kepada masyarakat miskin.

'If I am not mistaken, the rice from the government's aid is only for the poor.

(6) Maaf, kalau boleh saya berpendapat, pemecahan masalah sampah di kompleks ini jangan sekadar memperbesar bak sampah.

'Sorry, if I may argue, the solution of the garbage problem in this complex should not be limited to enlarge the garbage.'

(7) Jika memungkinkan, kegiatan peringatan Proklamasi Kemerdekaan Negara Republik Indonesia tidak hanya melibatkan laki-laki, tetapi juga perempuan.

'If possible, the commemoration activities of the Proclamation of Independence of the Republic of Indonesia are not only followed by men, but also women.'

Refusal speech acts (5) is conducted by a meeting participant to the other meeting participants in the distribution of the government's share of rice for the poor. A speaker rejected one participant's suggestion. The participant's suggestion is that rice be given to the poor and the elderly. One type of hedging used in speech acts (5) is a phrase kalau tidak salah 'if not mistaken'. Speaker's rejection towards conversational partner's request is softened using hedging in the form of a phrase kalau tidak salah 'if I am not mistaken'. The use of a phrase 'kalau tidak salah' if I am not mistaken in that speech implies that the speaker is 'hesitant to refuse' the addressee's opinion.

Refusal speech acts (6) is conducted by a meeting participant to another meeting participant in determining how to solve the waste problem in a housing complex. A speaker rejected one participant's suggestion. The suggestion of the meeting participants was to solve the increasing amount of garbage in the housing complex through the enlargement of the trash bin in the housing complex. One type of hedging used in speech acts (6) is an expression of doubt kalau boleh saya berpendapat 'if I may argue'. The speaker's rejection towards the suggestion of conversational partner is softened by using hedging in the form of an expression of doubt. The use of a hedging implies that the speaker does not want to impose his will on the addressee.

Refusal speech acts (7) is conducted by a meeting participant to another meeting participant to determine the contest participants on the anniversary of Independence Day of Indonesia in a housing complex. In this case, the speaker rejects someone's suggestion. The suggestion from a meeting participant was the race is only followed by men only in the housing complex. One type of hedging used in speech acts (7) is an expression of doubt jika memungkinkan 'if possible.' The speaker's rejection towards the addressee's suggestion is conducted by softening the statement through the use of hedging in the form of an expression of doubt. The use of a hedging implies that 'the speaker does not want to force his/her will on the addressee.'

Based on the Politeness Principles by Leech (1983), the hedging of doubtful and limitation of speakers' intentions belong to the maxim of generosity whereby the speakers likely to accept little profit and are willing to bear more loss. On the other hand, based on Speech Strategy Theory by Brown and Levinson (1987), the hedging of doubtful and limitation of speakers' intentions belong to 'bald on record' strategy with small talk of negative politeness whereby the speakers try not to disturb the addressee.

\section{Hegding and politeness of refusal speech acts}

The use of hedging in refusal speech acts serves to form the politeness of refusal speech acts such as the following examples of speech acts. To determine the effect of hedging on the politeness of refusal speech acts, an example of speech acts using a particular type of hedging is compared with an example of speech acts that do not use hedging.

The use of hedging in the form of apology and its effect on politeness in refusal speech acts can be seen in the following examples.

(8) a. Maaf saya tidak setuju, ada pelajaran tambahan bagi siswa pada hari minggu.

'Sorry I humbly disagree, there is an additional lesson for students on Sundays.'

b. Saya tidak setuju ada pelajaran tambahan bagi siswa pada hari Minggu.

'I do not agree there is an additional lesson for students on Sunday.'

Refusal speech acts (8a) is conducted by a parent of the student addressed to an elementary school principal presiding at a meeting between the school and the parents. The parent rejects the principal's plan to add hours of study on Sunday. Refusal speech acts (8a) applies hedging of maaf 'sorry'. Refusal speech acts (8b) is refusal speech acts that do not use hedging. Speech (8b) is a hypothetical speech act made by the author for the purposes of comparing the effect of hedging on the politeness of directive speech acts.

The informant of the research considered that speech acts (8a) that use hedging apology to the addressee is more polite than refusal speech acts $(8 \mathrm{~b})$ that do not use hedging. Refusal speech acts that uses hedging is considered more polite than speech without hedging because hedging maaf 'sorry' puts the speaker as humble party which appreciates the addressee and 
places the addressee in a higher position than the speaker. Based on Leech's theory of Politeness (1983), especially the maxim of modesty, speakers who are more humble in their speech, are judged to be more polite and vice versa.

The use of hedging in the form of softening intent and its effect on politeness in refusal speech acts can be seen in the following examples.

(9) a. Saya kurang setuju perpustakaan diletakkan di lantai paling atas.

'I hardly agree if the library is placed on the top floor.'

b. Saya tidak setuju perpustakaan diletakkan di lantai paling atas.

'I do not agree if the library is placed on the top floor.

Refusal speech acts (9a) is conducted by a teacher addressed to an elementary school principal presiding over a teacher council meeting to discuss the placement of a school library. A meeting participant rejected the principal's plan to place the library on the top floor. Refusal speech acts (9a) uses hedging softening the intent through the phrase kurang setuju 'hardly agree'. Refusal speech acts (9b) are refusal speech acts that do not use hedging. The informant of the research considered that the act of speech (9a) using hedging softening intentions to the addressee was more polite than refusal speech acts (9b). Refusal speech acts that use hedging are judged to be more polite because hedging is a softening of intentions perceived as not forcing or not burdening the addressee. Based on the pragmatic scale theory by Leech (1983), the more minimum the degree of coercion to the addressee then, the politeness of the speech act is higher.

The use of hedging in the form of expression of doubt and self-limitation and its effect on the politeness of refusal speech acts can be seen in the following examples.

(10) a. Sepanjang yang saya tahu, beras bantuan pemerintah tidak boleh diberikan kepada orang kaya. 'As far as I know, rice from government aid should not be given to the rich.'

b. Beras bantuan pemerintah tidak boleh diberikan kepada orang kaya!

'Rice from government aid should not be given to the rich!'

Refusal speech acts (10a) is conducted by a meeting participant addressed to a headman who led a rice distribution meeting for the poor. A meeting participant rejected the headman's plan that would distribute the rice from government aid to the aged people despite being able to afford. Refusal speech acts (10a) uses hedging of doubtful expression sepanjang yang saya tahu 'as far I know. Refusal speech acts (10b) is refusal speech acts without hedging. The informant of the research considered that the speech act (10a) using hedging of softening the intent to the addressee was more polite than the refusal speech acts (10b). A refusal speech act that uses hedging are considered more polite because hedging in the form of exposing doubt is felt not to force or not to corner the addressee.

Beberapa hedging dan sarana kesantunan yang lain sering digunakan dalam sebuah refusal speech acts. Penggunaan hedging dan sarana kesantunan yang lebih lengkap semakin meningkatkan kesantunan refusal speech acts seperti contoh-contoh tindak tutur berikut ini.

Some hedgings and other means of politeness are often used in a refusal speech acts. More complete use of hedging and politeness means increasing the politeness of refusal speech acts like the following examples of speech acts.

(11) a. Maaf, saya tidak setuju cara mengajarkan membaca dan menulis di Taman Kanak-kanak disamakan dengan cara pembelajaran membaca dan menulis si Sekolah Dasar.

'Sorry, I disagree if teaching method of reading and writing in Kindergarten is equated with elementary school level.

b. Maaf, saya kurang setuju cara mengajarkan membaca dan menulis di Taman Kanak-kanak disamamakan dengan cara pembelajaran membaca dan menulis si Sekolah Dasar.

'Sorry, I hardly agree if teaching method of reading and writing in Kindergarten is equated with elementary school level.'

c. Maaf, kalau boleh berpendapat, saya kurang setuju cara mengajarkan membaca dan menulis di Taman Kanakkanak disamamakan dengan cara mengajarkan membaca dan menulis si Sekolah Dasar.

'Sorry, if I may argue, I hardly agree if teaching method of reading and writing in Kindergarten is equated with elementary school level.'

Refusal speech acts (11b) is considered more polite than speech acts (11a) by respondent of the research because speech acts (11b) uses more complete hedging than speech acts (11a), so speech acts (11b) is perceived to be more elevated and less likely to interfere the freedom of conversational partner. In contrast, the act of speech (11a) is felt only to elevate the conversational partner. In other speech acts, refusal speech acts (11c) is considered more polite than speech acts (11b) by the respondent of the research because speech acts (11c) uses hedging more complete than speech (11b) therefore speech acts (11c) are felt to be respectful, minimize contradictory, and less likely to attack the addressee than in speech act (11b). 
Based on the above description, it can be seen that hedging is used by speaker to form politeness in refusal speech acts. The more complete the hedging used in a refusal speech acts, therefore the speech acts are judged to be more polite by the addressee. Based on Leech's theory of politeness (1983), the more obedient a speech acts towards the principles of politeness; therewith the level of politeness of speech acts is also higher.

\section{Hedging and speech events}

The relationship between hedging usage and speech event context can be seen in the following examples of speech acts. To find out the relationship between hedging and speech event contexts, the presentation of refusal speech acts is sorted by the most threatening speech event to the least threatening speech event.

The use of hedging in speech events that rejected participant is higher in rank of power $(+\mathrm{P})$, but has low degree of solidarity $(-\mathrm{S})$ is like the following example.

(12) Pak, sebelumnya saya minta maaf. Mungkin saya kurang setuju dengan pendapat Bapak.

'Previously, I am truly sorry, Sir. Perhaps, I hardly agree with your opinion.'

In speech event (+P-S), speaker generally uses hedging and more complete politeness devices. In refusal speech acts (12), 4 hedgings were used, whereby 2 hedgings of doubtful expression sebelumnya 'previously' and barangkali 'perhaps', 1 hedging of request maaf 'sorry', 1 hedging of softening the intention kurang setuju 'cannot agree'.

Penggunaan hedging pada speech event, yaitu orang yang ditolak lebih tinggi kedudukannnya $(+\mathrm{P})$, tetapi tingkat solidaritasnya tinggi $(+S)$ adalah seperti contoh berikut ini.

The use of hedging in speech events that rejected participant is higher in rank $(+\mathrm{P})$, but has high degree of solidarity $(+\mathrm{S})$ is like the following example.

(13) Maaf ya Pak, bukan saya menolak pemberian Bapak, tapi saya merasa tidak pantas menerimanya.

'Without intention to reject your present, I am so sorry sir; I feel it is inappropriate to receive it.'

In speech event $(+\mathrm{P}+\mathrm{S})$, speaker generally uses less hedging and less politeness devices than in the speech event (+P-S). In refusal speech acts (13), 3 hedgings were used, whereby 1 hedging maaf 'sorry', 1 hedging of agreement ya Pak 'yes sir' and 1 hedging of doubtful expression bukan saya menolak 'without intention to reject'.

The use of hedging in speech events that rejected participant is equal in rank og power $(=\mathrm{P})$, but has low degree of solidarity (-S) is like the following example.

(14) Menurut saya, pendapat kamu bagus, tetapi saya masih kurang setuju dengan pendapatmu.

'I think your opinion is good, but I still do not agree with your opinion.'

Dalam tindak tutur menolak (14), digunakan 2 hedging dan 1 pujian, yaitu 1 hedging pengungkapan pembatasan menurut saya, 1 hedging pelunakan penolakan kurang setuju, dan 1 pujian pendapat kaти bagus.

In refusal speech act (14), speaker uses 2 hedgings and 1 praise, whereby 1 hedging for limitation I think, 1 hedging for softening the refusal kurang setuju 'I do not agree' and 1 praise pendapat kamu bagus 'your opinion is good'.

The use of hedging in speech events that rejected participant is lower in rank (-P), but has low degree of solidarity (-S) is like the following example.

(15) Hadirin sekalian, sebelumnya saya minta maaf karena saya belum bisa menerima usulan hadirin.

Ladies and gentlemen, beforehand, I apologize because I cannot accept the proposal.

In speech event (-P-S), speaker generally uses hedging and politeness device that tend to be more complete than speech event $(=\mathrm{P}+\mathrm{S})$. In refusal speech acts (14), 3 hedging were used, whereby 1 hedge of limtation sebelumnya 'beforehand limitation', 1 hedging of request maaf 'sorry' and 1 softening rejection belum bisa menerima 'cannot accept'.

The use of hedging in speech events that rejected participant is lower in rank (-P), but has high degree of solidarity $(+\mathrm{S})$ is like the following example.

(16) Maaf, saya tidak bisa menerima permintaanmu.

'Sorry, I cannot accept your request.'

In speech events $(-\mathrm{P}+\mathrm{S})$, speaker generally uses hedging and politeness device that tend to be less than speech events (-P$S)$. In the speech act of refusing (16), the speaker uses one hedging, i.e., one hedging of apology.

Based on the above description, it can be seen that in the context of speech events, the rejected addressee is increasingly unfamiliar with the speaker then informants generally use a more complete hedging to form politeness in the refusal speech acts. Based on the strategy theory of Brown and Levinson (1987), one of the parameters of the FTA level is the level of solidarity between speakers and the addressee. The lower the solidarity relationship between the speaker and the addressee then the higher the FTA level against addressee. Speech events that contain high level of FTA require more complete face-protection devices. 
The results of the study in this article are similar to the results of the study in the articles written by Anggraeni (2005), Manaf (2010 and 2011), and Yazdanfar and Bonyadi (2016). The similarity of the results of the study in this article with the results of the study in the article above is as follows. Hedging was used to mitigate the intent of the speaker in the refusal speech acts so that the addressee does not seem to be disturbed by his freedom or attacked by the speaker's speech. Hedging is used together with other language tools where the types and numbers are adjusted to the context of the speech events. Refusal speech acts performed in the context of speech events that contain a high level of FTA generally use more complete hedging than in speech events that contain low levels of FTA.

\section{CONCLUSION}

The results of this study are as follows. First, there are three types of hedging used in the refusal speech acts in the Indonesian language, namely (1) apology, (2) minimizing or softening intentions, and (3) the expression of doubt. The use of hedging in the speech acts forms the impression of minimizing a rejection and minimizing the disruption towards the addressee so that speech acts are perceived as polite by the addressee. Generally, the speech act is accompanied by more than one hedging and added other means of politeness. Third, hedging is used in speech situations that contain the highest level of vulnerability up to the lowest, but the major one is used in situations where the relationship of solidarity between speakers and addressee is low. In speech events that contain high levels of facial vulnerability, the speech acts tend to use hedging and other means of more complete politeness. On the contrary, in speech event that contain low levels of facial vulnerability, speech acts are equipped with hedging and lesser means of politeness.

\section{References}

Austin, J.L. (1962). How to do thing with words. New York: Oxford University. Press.

Blum-Kulka, S. (1987). Indirectness and politeness in request: Same or different? Journal of Pragmatics, I, 131 -146.

Brown, P. dan Levinson, S.C. (1987). Politeness: some universals in language usage. Cambridge: University of Cambridge Press.

Codreanu, A. and Debu, A. (2011). Politeness in request: Some researh findings relevant in for intercultural encunters. Juornal of Defens Resurces Management. No. 2 (2) 2011, 127-136.

Leech, G. (1983). Principles of pragmatics. London: Longman.

Manaf, N.A. (2010). Peminimalan beban dan peminimalan paksaaan sebagai cara berperilaku santun dalam berbahasa Indonesia. Jurnal Pendidikan dan Kebudayaan. Vol. 16, No. 1, 38-50.

Manaf, N.A. (2011). Kesopanan tindak tutur menyuruh dalam bahasa Indonesia. LITERA. Vol. 10, No. 2, 212 -225.

Manaf, N., A. dan Amir, A. (2015). Speech act prohibit politely in Indonesian with respect courtecy by member Minangkabau ethnic group. Prosiding the International Seminar on Languages and Arts (ISLA)-4. FBS UNP, Padang, 23-24 Oktober $2015,371--376$.

Purnomo, B. (2011). Tourism-service language: acrosscultural perspective on politeness. Humaniora. Vol. 23, No. 2 Juni 2011, 185-198.

Searle, J. R.(1975). Indirect speech act . Di dalam P. Cole dan J. Morgan (ed.). Syntax and semantics Vol. No. 3, 59 -82.

Searle, J. R. (1976). The clasification of ilucutionary acts. Language and Society 5, 1-24.

Susanto, D. (2014). The pragmatic meanings of address terms sampeyan and anda. Indonesian Journal of Applied Linguistics. Vol. 4. No. 1. Juli 2014, 140-155.

Tawalbeh, A. and Al-Oqaily, A. (2012). In-direcness and politeness in American English and Saudi Arabic requests: Acrosscultural comparation. Asian Social Science. Vol. 8 No. 10, August 2012, 85-98.

Trosborg, A. 1995. Interlaguage pragmatics Request, Complaints, and apologies. New York: Mouton de Gruyter.

Vega, G.T. and Azókar, S.T. (2014). Politeness strategies for request in Chilean Spanish native speaker and Spanish foreign language speaker. ONOMÁZEIN, 29 (junio de 2014), 47-63.

Yasdanfar, S., Bonyadi. A. (2016). Request strategies in everyday interaction of Persian and English Persian. SAGE open. Ocktober-December 2016, 1-11. 